\title{
Suckling Behavior of Piglets in a Family Pen System
}

\author{
Hajime Tanida, Taku Sarto, Toshio Tanaka \\ and Tadashi Yoshimoto \\ School of Veterinary Medicine, Azabu University \\ Sagamihara-shi 229
}

(Received September 2, 1991)

\begin{abstract}
Two experiments were carried out in order to study the suckling behavior of piglets in a family pen system $(11 \mathrm{~m} \times 14 \mathrm{~m})$ where 2 boars, 6 to 7 sows and variable number of litters were housed in a group. In Experiment 1, the first litter was moved into the system from a farrowing crate at 2 weeks of age and remained there after weaning at 30 days of age. The second litter was then introduced into the system. The weaners whose mother had left the herd for remating started to suckle a sow within the group in the last stages of pregnancy. She started to secrete milk before parturition and failed to raise her own piglets. When young piglets and their mother were introduced into the group, the weaners switched the suckling target to this alien mother whose own piglets were occasionally squeezed out at suckling. In Experiment 2, which attempted to improve the system of Experiment 1, three different litters of suckling piglets were introduced into the system, and they were all moved out of the system at weaning at 30 days of age. The nursing behaviors of the three sows were highly synchronized, and the suckling behavior of piglets had a tendency to be dispersed across the three different sows. No piglets attempted to suckle from pregnant sows. The result of cluster analysis on the time spent on suckling behavior by piglets showed that piglets had a closer associations toward littermates than with piglets from other litters. As an additional observation in Experiment 2, one sow came into heat during lactation. In both experiments, neither fighting among adult pigs nor aggressive actions by adult pigs on piglets were observed. The present results suggest the possibility of the practical use of a family pen system as an alternative to present management systems.
\end{abstract}

Anim. Sci. Technol. (Jpn.) 63 (2) : 148-156, 1992

Key words : animal welfare, piglets, family pen system, suckling behavior, feed station

Most pregnant sows in Japanese pig production are confined in small stall system, and their behaviors are severely restricted. Main body movements allowed are either standing up or lying down, and they have little opportunity to walk and run throughout their lives. The system also limits their social contacts with other individuals although pigs are said to be social animals.

Confinement systems such as stalls and tethers have been designed to maximize produc- tion efficiency per unit of space. However, the emergence of abnormal behavior and a consequent reduction of productivity per individual animal have been reported in the system ${ }^{5,12-14}$. This may result in impaired animal welfare, and reduced production efficiency and profit.

It is urgent to identify management practices which satisfy both animal and human welfare. One approach is to house pigs under less restricted conditions in groups so that they have greater opportunity for social interactions 
and freedom of behavior. This would be expected to reduce abnormal behavior patterns. A family pen system has been advocated by Stolba ${ }^{11)}$ to enhance welfare for adult pigs and piglets. The system allows not only keeping a group of sows but also including boars and litters in one yard in which pigs of different ages could have free social contacts. In such systems, a possible problem is that the farmers would not be able to feed sows individually, according to body weight and stage of pregnancy. A recent technical advancement, however, made it possible. Computer controlled feeding stations and transponders allowed individual feeding management in group housing of pregnant sows ${ }^{1}$. We incorporated the devices into a family pen system.

The social relationships of domestic piglets kept with adult pigs in a large outside enclosure have been studied by a few research$\mathrm{ers}^{8-10)}$. Interactions among different litters at suckling in the family pen system, however, do not appear to have been studied. Such studies could help to understand a family pen system better and also to realize the practical use of the system.

The purpose of the present experiment was to study the suckling behavior of sows and piglets in a family pen system equipped with a computer controlled feeding station when housed in different group compositions.

\section{Materials and Methods}

\section{Housing}

The study was conducted at Azabu University. The herd was comprised of six to seven sows (Large White and its crosses), two boars (Large White) and a variable number of litters. A family pen system $(11 \mathrm{~m} \times 14 \mathrm{~m})$ contained an outdoor area and three pens in a piggery, which all were connected throughout (Fig. 1). The pigs were able to interact freely in the system. The indoor pens had a concrete floor and each contained a water cup. The end pen was occasionally used either as a mating pen or

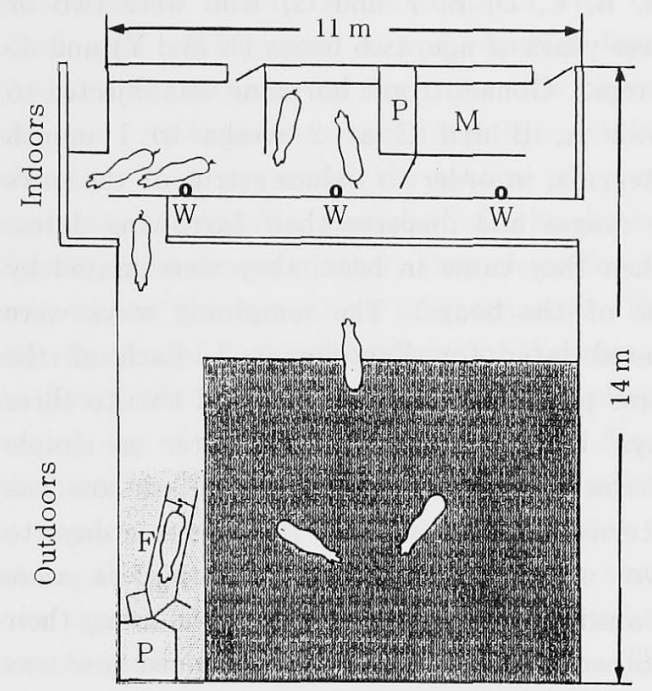

Fig. 1. A family pen with a computer controlled feeding station.

$\mathrm{E}=$ computer controlled feeding station with roof

$\mathrm{W}=$ water cup

$\mathrm{M}=$ multi-purpose pen

$\mathrm{P}=$ piglet shelter

The shaded area is soil and the rest of the area is concrete.

as a simple farrowing crate. Small crates that only piglets could enter for rest and eating synthetic milk were available both in the outdoor yard and inside the piggery. Adult pigs were all fed at a computer controlled walkthrough feeding station (Nedap : Porcode) installed in the corner of the outdoor area. When a pig entered the feeding station, the computer read the identification number on the responder of circular collar which was placed over the pig's head. The pig was allowed to feed if it had a positive feed balance.

\section{Experiment 1: weaners kept in the group}

The objective of Experiment 1 was to study the suckling behavior of piglets in a family pen system where weaned piglets and suckling piglets were housed together.

Four months before the initiation of the experiment, the group consisted of seven sows 
(A, B, C, D, E. F and G) who were two or three years of age, two boars ( $X$ and $Y$ ) and no litters. Gonadotropic hormone was injected to Sows A, B and C at 2 weeks to 1 month intervals, in order to induce estrus of the sows by stages and disperse their farrowing dates. When they came in heat, they were mated by one of the boars. The remaining sows were mated later for Experiment 2. Each of the three pregnant sows left the herd two to three days before parturition to enter a simple farrowing crate in the end pen. Each sow was returned to the herd with its litter ten days to two weeks post-partum. The piglets were weaned at thirty days of age by removing their mother from the herd. Each weaned sow was then individually mated by one of the boars at the reoccurrence of estrus and was then returned to the herd.

These procedures created different social environments in the family system. During the first stage, the group consisted of Boar X, its weaned piglets (Weaners A) of Sow A (who already had left the herd), Sow $C$ (who was in the last stages of pregnancy), Boar $Y$ and four other sows at various stages of pregnancy. During the second stage, the group consisted of Boar X, Sow B, their suckling piglets (Piglets $B$ ), Weaners $A$, the adult boar $Y$ and the other pregnant sows. Weaners $A$ and Piglets $B$ consisted of 7 and 5 piglets, respectively.

The behavior of the piglets was observed during stage 1 to study the influence of weaned piglets on the behavior of a sow in the last stage of pregnancy and at stage 2 to study the influence of weaned piglets on the behavior of suckling piglets. An infra-red video camera was installed on the roof of the piggery for outside observation and a color video camera with a wide lens was hung from the ceiling for inside observation. Both cameras were connected to time-lapse video recorders. The pens had continuous artificial lighting. The observations for stage 1 were conducted on the day after Sow $A$ was moved from the herd for weaning and again one week after that day. They were respectively called the first and second observation day of stage 1 . The observations for stage 2 were conducted on the day after Sow $B$ and her piglets were returned to the herd, and again one week and two weeks after that day. They were respectively called the first, second and third observation day of stage 2. On each observation day, the video recording was conducted for $24 \mathrm{~h}$ started at 0800. Before the observation started, identification numbers were painted on the back and both side of each adult pig. Individual identification for piglets was not made in either stage, but in stage 2, Weaners A and Piglets B were easily discriminated by size.

For stage 1, the number of Weaners A engaged in suckling behavior toward Sow $\mathrm{C}$ was counted every minute on each observation day. For the stage 2, the numbers of Weaners $A$ and Piglets $B$ engaged in suckling behavior toward Sow B were counted every minute on each observation day.

Experiment 2: three different litters of suckling piglets mixed

The objective of Experiment 2 was to improve the system used in Experiment 1. Ten days after the end of the experiment 1 , the pig group consisted of six sows (A, B, D, E. F and $\mathrm{G}$ ) and two boars ( $\mathrm{X}$ and $\mathrm{Y}$ ) was formed. Gonadotropic hormone was injected to Sows $\mathrm{E}$, $F$ and $G$ at a few days interval, in order to create the environment in which three litters of suckling piglets (Piglets E, F and G) would be in a family pen system during the same period. Piglets E, F and G consisted of 10,10 and 12 piglets, respectively.

Each of the three pregnant sows left the herd a few days before parturition for introduction into a conventional farrowing crate. All three sows were back to the herd with their litters in 10 days to two weeks post-partum. The piglets were weaned at thirty days of age by removing them from the herd. The weaned sows were then naturally mated by one of the 
boars in the herd.

Behaviors of Piglets $\mathrm{E}, \mathrm{F}$ and $\mathrm{G}$ were observed to study the interactions among the litters during suckling with the same video instruments as Experiment 1. Three observations were conducted at one week intervals during the period during which Sow E, F and G and their litters were in the herd. On each observation day, the video recording was conducted from $09: 00$ to $12: 00,17: 00$ to $20: 00$ and $01: 00$ to $04: 00$, and data were recorded only when at least half the piglets of a litter were nursing. Further, sucking behaviors of each individual of the three litters were recorded every 30 seconds from $09: 00$ to $12: 00$ on each observation day by observers. Before the observation started, identification numbers were painted on the back and both side of each adult pig and piglet.

The degree of association among piglets was analyzed by cluster analysis ${ }^{7)}$ on the time spent on suckling behavior toward the same sow to study interactions among different litters at suckling.

\section{Results}

Experiment 1: When Sow A with her piglets were reintroduced from the farrowing crate to the system, the attitude of other members in the herd toward them was peaceful, and no aggression against Sow $\mathrm{A}$ was observed. The piglets ran around the system vigorously and attempted to initiate social contacts with the adult pigs. When Sow A was removed from the herd for weaning of her litter, the piglets (Weaners A) began to search for other suckling objects. They examined the udders of pregnant sows and the testicles of the boars. Finally, as a foster mother, they chose Sow C who was in the last stages of pregnancy. The distribution of suckling behavior of Weaners $A$ on Sow $\mathrm{C}$ throughout $24 \mathrm{~h}$ on the second observation day of stage 1 is shown in Fig. 2. Since the result of 1 st observation day was similar, it is not presented. Weaners A suckled Sow C at regular intervals as if suckling from their own mother. In consequence, Sow C started to secrete milk two weeks before parturition. The sow farrowed six piglets, but five of them died of malnutrition.

In stage 2, mother Sow $B$ and her litter (Piglets B) were reintroduced to the herd. The behaviors of the herd toward them were similar to what Sow $A$ and her litter had experienced. Weaners A were 2 weeks older than piglets $B$. They were playing and chasing each other in spite of the differences in body size and age. Weaners A quickly changed the suckling target from Sow $C$, which had left the herd for farrowing, to alien mother Sow B. The distribution of suckling behavior of Weaners A and piglets B on Sow B throughout $24 \mathrm{~h}$ on the third observation day of stage 2 is shown in Fig. 3. Since the results of 1 st and

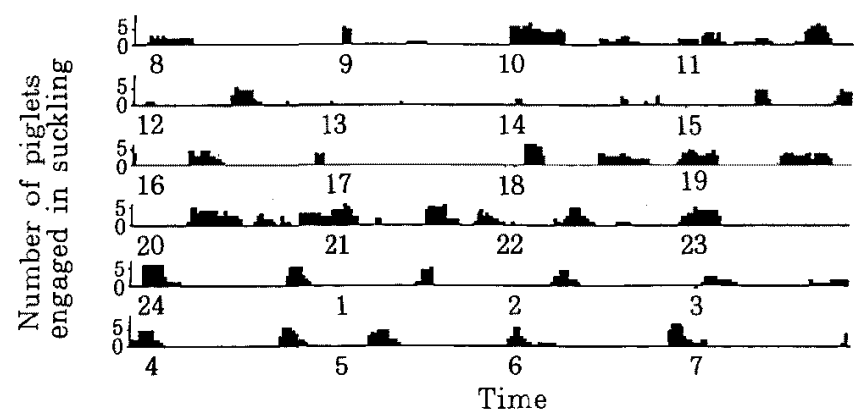

Fig. 2. The distribution of suckling behavior of Weaners $A$ on Sow $\mathrm{C}$ throughout $24 \mathrm{~h}$ on the second observation day of stage 1. 


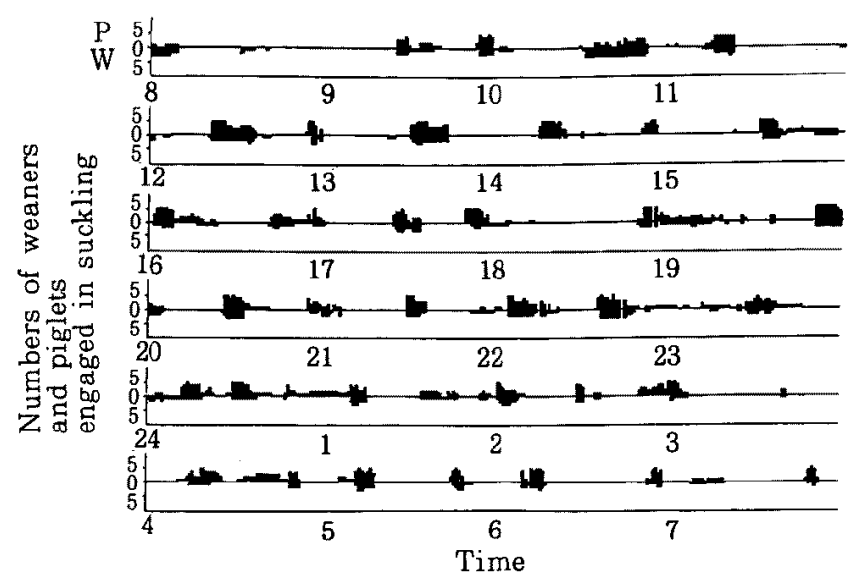

Fig. 3. The distribution of suckling behavior of Weaners $A$ and Piglets B on Sow B throughout $24 \mathrm{~h}$ on the third observation day of stage 2.

$\mathrm{P}=$ Piglets $\mathrm{B}$

$\mathrm{W}=$ Weaners $\mathrm{A}$

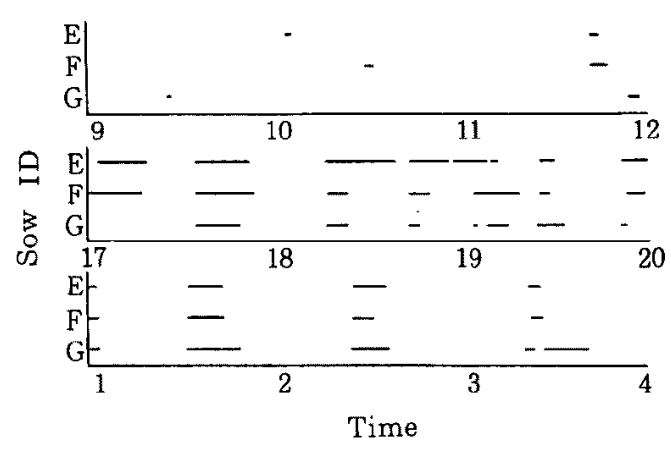

Fig. 4. The distribution of nursing behaviors of Sows $\mathrm{E}, \mathrm{F}$ and $\mathrm{G}$ from 09.00 to 12.00 , 17.00 to 20.00 and 01.00 to 04.00 on the third observation day.

2nd observation day were similar, they are not presented. The suckling behavior of Weaners $A$ and piglets $B$ were synchronized on all three observation days. Weaners A occasionally pushed out suckling Piglets B and stole milk from Sow B.

Experiment 2: The distribution of nursing behaviors of Sows $E, F$ and $G$ from 09.00 to $12.00,17.00$ to 20.00 and 01.00 to 04.00 on the third observation day is presented in Fig. 4. The nursing behaviors of the three sows largely were synchronized, particularly in the afternoon and night periods. The sucking behavior of piglets had a tendency to be dispersed across the three different sows, and the concentration of piglets on one particular sow was not observed. Also no piglets attempted to suckle from pregnant sows.

The associations among piglets within and between litters based on the time spent on suckling behavior toward the same sow were determined by cluster analysis and are illustrated in the form of dendrograms in Fig. 5. Individuals with a strong association were linked on the dendrograms at a low level. The associations of piglets were much stronger between littermates than between piglets from different litters, but a few piglets such as Gl, $\mathrm{Gj}$ and $\mathrm{Gh}$ came and went between different sows and frequently suckled with piglets of a different litter. As an additional observation, one sow came into heat while nursing its piglets during lactation, which was also reported in the family pen system by Stolba ${ }^{10)}$ 


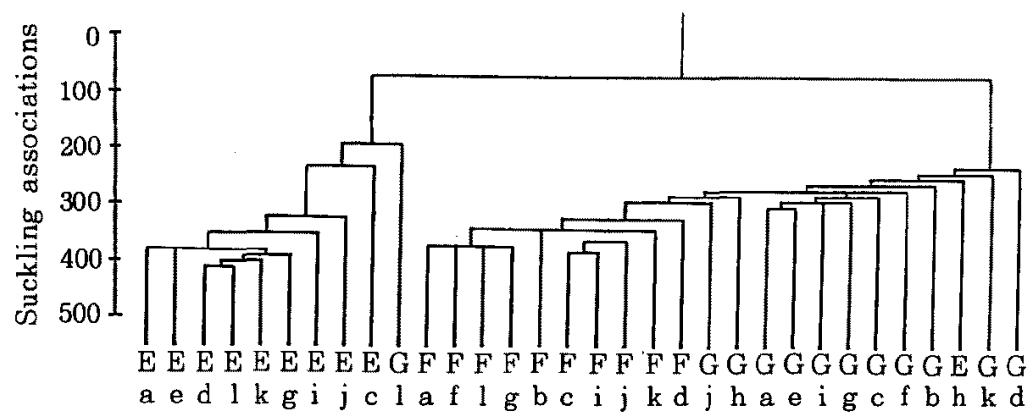

Piglets ID

Fig. 5. Dendrograms of suckling associations among piglets within and between litters based on the time spent on suckling behavior toward the same sow. Individuals with a strong association were linked on the dendrograms at a low level. The numbers on the vertical axis suggest the degree of association based on cluster analysis. The small letters in the figure mean piglets ID within a litter.

\section{Discussion}

A couple of problems arose in the family pen system of Experiment 1. One of the problems was that weaners started to suckle a sow that was in the last stages of pregnancy. The sow accepted them and assumed a nursing posture. As the result, she started to secrete milk before parturition. She later farrowed six piglets but five of them died of malnutrition since she was not milking well for her own piglets. There is a possibility that colostrum for newborn piglets had already been consumed by the weaners. The weaners attempted to suckle other pregnant sows and even the testicles of boars in the herd, but these adult pigs did not assume a nursing posture for the weaners, which discouraged their further attempts to suckle.

Another problem was that the weaners stole milk from another sow that was retuned to the herd with its litter. The weaners squeezed themselves between suckling piglets and a few piglets were always pushed out of the suckling crowd. The average weaning time of domestic pigs in a semi-natural environment was reported to be 17.2 weeks $^{6)}$. Further, Jensen ${ }^{4)}$ reported an increase in time of pre-massage by piglets during suckling at 10 to 15 weeks post-partum, but a decrease in the frequency of lying and nursing by mothers between 1 to 4 weeks post-partum in pigs under free-range conditions. These findings show that piglets demand for milk for quite an extended period, although the mothers become increasingly unwilling to nurse as lactaion proceeds. The sows either in the last stages of pregnancy or early post-partum could be lucky windfalls for weaners in the system. The weaners, which were artificially separated from their dam but were still motivated to seek milk could easily find an alternative milk source in the system. These two problems suggest that the farrowing date of all sows ought to be similar, and the piglets should be moved out of the system at weaning.

In Experiment 2, the sows $\mathrm{E}, \mathrm{F}$ and $\mathrm{G}$ were farrowed at a few days interval to create the environment in which three similarly aged litters of piglets (Piglets E, F and G) were housed in the family pen system, and all piglets were moved out of the system at weaning. Each litter had a tendency to suckle only from its own mother; and milk stealing, which was seen frequently in weaners in 
Experiment 1, was rarely observed. The piglets associations during suckling events were stronger between littermates than between piglets of different litters. Our findings are in accordance with Petersen et al. ${ }^{10}$ and NEWBERRY and WOOD-GUSH ${ }^{9}$, who reported that piglets had stronger social relationships with littermates than with other members of the group. Since each mother sow and its piglets were artificially isolated in a conventional farrowing crate for 2 weeks after parturition in the present experiment, it seems that the mothers and their piglets had formed a strong social bond during this period and this relationship continued even after they were moved to the system. Petersen et al. ${ }^{10)}$ stated that the isolation of the female from her social group around parturition had an important role in forming a close attachment between the mother and offspring from imprinting-like processes. This has been also found in the wild boar sow which becomes solitary from her social group before farrowing ${ }^{2)}$.

A few piglets, however, occasionally attempted to steal milk from alien mothers. Most of the stealings were successful without any aggression from the alien mothers. The piglet $G 1$ and En had switched from suckling from its own mother to an alien mother and had become a foster piglet. These observations were in accordance with the study of piglets in a semi-natural environment by NEWBERRY and WOOD-GUSH ${ }^{8)}$. According to Jensen's observations $^{3 \text { ) }}$ in free-ranging domestic pigs, however, most of such stealing attempts were prevented by the piglets of the nursing sow. In the present experiment, such preventions were rarely observed, probably because each sow had a few extra unoccupied teats. In a sense, this act is not stealing but rather simply switching the teat from one sow to the other since no piglets were harmed by the behavior. The results of Experiment 2 shows that piglets do not take interest in suckling from pregnant sows as weaners did in Experiment 1 and milk steaing offers no problem, as long as the farrowing dates of the sows are similar in the system.

In both Experiment 1 and 2, neither fighting attempts nor aggressive acts by other group members toward the sows and their piglets introduced from farrowing crates were observed. Before the experiments, we were concerned of fighting among them, including cannibalism of piglets by boars, since we have been acquainted with severe fighting when pigs were mixed in daily management. The reasons for the peaceful interactions are presumably because the sows were originally the members of the herd prior to their two weeks absence.

Our study suggests that the family pen is a peaceful group housing system and practical use of the system as an alternative to the current pig management is quite within the bounds of possibility. More field studies, however, are necessary in the future.

\section{Acknowledgement}

This work was supported in part by Nissan Science Foundation, Japan. We thank professor W.D. Hohenboken at Virginia Polytechnic Instituse and State University for his constructive criticism of this manuscript.

\section{References}

1) Edwards, S.A. and J.E. RLEY, The application of the electronic identification and computerized feed dispensing system in dry sow housing. Pig News and Information, $7: 295-298.1986$

2) Graves, H.B., Behavior and ecology of wild and feral swine (Sus Scrofa). J. Anim. Sci., 58 : 482-492. 1984.

3) Jensen, P., Observations on the maternal behaviour of free-ranging domestic pigs. Appl. Anim. Behav. Sci., 16 : 131-142. 1986.

4) Jensen, P., Maternal behaviour and mother-young interactions during lactation in free-ranging domestic pigs. Appl. Anim. Behav. Sci, 20 : 297-308. 1988.

5) Jensen, P., Diurnal rhythm of bar-biting 
in relation to other behaviour in pregnant sows. Appl. Anim. Behav. Sci, 21 : 337346. 1988.

6) JENSEN, P., When to wean-Observation from free-ranging domestic pigs. Appl. Anim. Behav. Sci., 23 : 49-60. 1989.

7) Morgan, B.J.T., M.J.A. Stmpson, J.P. HANBY and J. HALL-CRAGGS, Visualizing interaction and sequential data in animal behaviour: Theory and application of cluster-analysis methods. Behaviour, 56 : 1-43. 1976.

8) NeWBERRY, R.C. and D.G.M. WoOD-Gush, The suckling behaviour of domestic pigs in a semi-natural environment. Behaviour, $95: 11-25.1985$.

9) Newberry, R.C. and D.G.M. Wood-Gush, Social relationships of piglets in a seminatural environment. Anim. Behav., 34: 1311-1318. 1986.

10) Petersen, H.V., K. Vestergaard and P.
JENSEN, Integration of piglets into social groups of free-ranging domestic pigs. Appl. Anim. Behav. Sci., 23 : 223-236. 1989.

11) Stolba, A., Alternatives to intensive husbandry systems. 52-67. UFAW. Hertfordshire. 1981.

12) Stolba, A., N. Baker and D.G.M. WoOdGusH, Characterisation of stereotyped behaviour in stalled sows by informational redundancy. Behaviour, $87: 157-182$. 1984.

13) VAN Putren, G., Farming beyond the ability for pigs to adapt. Appl. Anim. Behav. Sci., 20 : 63-71. 1988.

14) Vestergaard, $K$. and L.L. Hansen, Tethered versus loose sows: Ethological observations and measures of productivity. I. Ethological observations during pregnancy and farrowing. Ann. Rech. Vet., 15 : 245-256. 1984. 


\title{
ファミリーペンシステムにおける子豚の吸乳行動
}

\author{
谷田 創・齋藤 拓・田中智夫・吉本 正
}

麻布大学獣医学部, 相模原市 229

慗殖豚の家族群飼管理モデル（ファミリーペンシステム）の有用性を検討することを目的とし，今回 はこのシステムにおける子豚の吸乳行動について2つの実験を行なった。ファミリーペンを形成するに あたって，まず理雄豚 2 頭と繁殖雃豚 7 頭を群飼した，成豚への飼料給与は，コンピュータ自動給慨機 を用いて個体別に行なった，実驗 1 : 成豚，離乳後の子豚（離乳子豚），離乳前の子豚 (哺乳子豚）か らなるファミリ一群を構成した，その結果, 離乳子豚は, 妊娠後期の雌豚に対して定期的に吸乳行動を 起こし，この㳔豚は分婏前に乳汁を分泌するようになり，その後，6頭の子豚を分婏したが，そのうち 5 頭は栄養不良により夜弱死した。 また, 離乳子豚が, 晡乳子豚の吸乳行動とその母豚の授乳行動のサ イクルに同期して，乳を盗むことが観察され，離乳した子豚をファミリーペンの中で継続して飼育する ことは，妊娠中の雌豚に悪影響を及隹すだけでなく，哺乳子豚の吸乳行動をす阻害することが認められ た、実験 $2:$ 尖験 1 のステムを改善し，離乳子豚を含めずに，成豚と，出生時期の近い翼腹子豚だけ からなるファミリー群を構成した，その結果，母豚の授乳行動には同期性か認められ，子豚の吸乳行動 が各母豚に分散したため，1頭の母豚に集中することはなかった。また，娃娠中の雌豚に対して子豚が 吸乳行動を起こすことむなかった，群内の繁殖䊒豚の分㴔時期をそろえ，離乳時に子豚を群れから隔離 することにより，好張雌豚に対する吸乳行動を防止するとともに乳の盗み飲みも無くし，行動の自由を 与えられた成豚と子豚を一つの群れとして総合的に管理することができた，

今回の調查結果から, 従来のストール飼育に代わる繁殖雌豚の管理法上してファミリーペンの実用化 の可能性が示唆された.

日畜会報， $63(2) ： 148-156,1992$ 